\title{
O eco escravista: Processo histórico de formação da seletividade penal
}

DOI: 10.15175/1984-2503-201810307

Eugeniusz Cruz

\begin{abstract}
Resumo
Este artigo enfoca o processo histórico de formação da seletividade penal no Brasil, com um recorte específico para a situação jurídica e social dos afrodescendentes, representados em uma moldura de desqualificação moral e racial pelo pensamento político e jurídico hegemônico. Delimitamos nossa observação do sistema penal dentro dos espaços urbanos. Analisamos as legislações penais do período imperial e as das primeiras décadas do regime republicano, quando ocorre a transição de regime político (de monarquia para a república) e a abolição da escravidão. Situamos nesta conjuntura o aparecimento de demandas por mais repressão penal, quando ocorre exploração da sensação de insegurança e de fragilidade política. A análise é direcionada a partir do encaminhamento epistemológico de Gaston Bachelard, e a investigação ocorre no enfrentamento ao pensamento hegemônico, através de aberturas, fratura e ranhuras no pensamento absolutista e autoritário que direciona e rege o agir dos sistemas punitivos.
\end{abstract}

Palavras-chave: História; Direito; escravidão; seletividade penal.

\section{El eco esclavista: el proceso histórico de formación de la selectividad del sistema penal}

\section{Resumen}

Este artículo aborda el proceso histórico de formación de la denominada selectividad del sistema penal en Brasil, con una reflexión específica sobre la situación jurídica y social de los afrodescendientes, representados en un marco de descalificación moral y racial por el pensamiento político y jurídico hegemónico. Delimitamos nuestra visión del sistema penal dentro de los espacios urbanos. Analizamos las legislaciones penales del período imperial y de las primeras décadas del régimen republicano de Brasil, cuando tiene lugar la transición del régimen político (de monarquía a república) y la abolición de la esclavitud. Situamos en esta coyuntura la aparición de demandas por mayor represión penal, cuando se revela necesario ahondar en la sensación de inseguridad y fragilidad política. El análisis está encauzado según las pautas marcadas por Gaston Bachelard y la investigación del enfrentamiento al pensamiento hegemónico, a través de aberturas, fracturas y ranuras en el pensamiento absolutista y autoritario que marca y rige la actuación de los sistemas punitivos.

Palabras clave: historia, derecho, esclavitud, selectividad del sistema penal.

The echo of slavery: the historical process shaping penal selectivity

\section{Abstract}

The following article discusses the historical process shaping penal selectivity in Brazil, with a specific focus on the legal and social circumstances of the population of African descent, represented by hegemonic political and legal thought in a framework of moral and racial disqualification. We restrict our observations to the penal system within urban spaces, analyzing the penal legislations of the Imperial period and those of the early decades of the Republican regime, in light of the transition from the political regime (monarchy to republic) and the abolition of slavery. We locate the emergence of demands for greater penal repression to this period, in the light of an exploitation of a feeling of uncertainty and political fragility. The analysis is guided by a reading of Gaston Bachelard and research into the clash with hegemonic thought, by means of openings, cracks, and breaks in the absolutist and authoritarian thought that characterizes and governs the workings of punitive systems.

Keywords: History; Law; slavery; penal selectivity.

Doutorando do Programa de Pós-Graduação em Sociologia e Direito da Universidade Federal Fluminense. Professor auxiliar de Direito Penal e Mestre em Direito como aluno bolsista da CAPES, pela Universidade Estácio de Sá. E-mail: eugeniuszcruz@gmail.com. Orcid ID: https://orcid.org/0000-0003-2430-8723 
L’écho esclavagiste : processus historique de formation de la sélectivité pénale

\section{Résumé}

Cet article s'intéresse au processus historique de formation de la sélectivité pénale au Brésil sous l'angle spécifique de la situation juridique et sociale des afro-descendants, que la pensée politique et juridique hégémonique tend à disqualifier aussi bien moralement que racialement. Nous avons à cette fin mené des observations du système pénal au sein des espaces urbains et analyser les législations pénales de la période impériale et des premières décennies du régime républicain, soit à l'époque de la transition de régime politique (de la monarchie à la république) et de l'abolition de l'esclavage. C'est dans cette conjoncture que nous situons l'apparition de demandes visant le renforcement de la répression pénale par le biais de l'exploitation du sentiment d'insécurité et de fragilité politique. Ce travail se fera sur la base des idées de Gaston Bachelard et de l'analyse des résistances à la pensée hégémonique par l'entremise des fractures et des failles de la pensée absolutiste et autoritaire qui caractérise et régit l'action des systèmes punitifs.

Mots-clés : Histoire ; Droit ; esclavage ; sélectivité pénale.

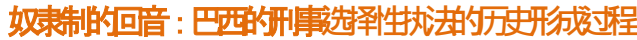 \\ 摌要}

本文主要讨论巴西刑事司法制度中的选择性执法的历史形成过程, 并特别关注巴西非洲裔的法律和社会状况, 这些非裔的法律和社会地位都被主流政治法律思想从道德上和种族上被贬低和损害。我们在给定的城市空间内 对巴西刑法制度进行观察。我们分析了帝国时期和巴西实行共和制的第一个十年期间的刑法, 在这段历史时期 巴西的政体发生了变化(从君主制转变为共和制), 并且在此期间, 推翻了奴隶制。在这个背景下, 巴西民众中出 现了严格执法的诉求, 因为在此期间, 巴西政治上混乱, 治安恶化, 这都成了针对黑人的选择性执法的理由。我 们根据法国当代哲学家Gaston Bachelard

的理论分析研究了在奴隶的反抗之下, 巴西权威主义和绝对主义思想出现的某些裂痕, 以及巴西刑法的惩罚机 制针对其自身的裂痕采取的补救措施一针对奴隶的选择性执法。

关键词 :历史, 法律, 奴隶制, 开怯上的筦择性执法。

\section{Introdução}

A presente pesquisa investigará o processo histórico de construção da seletividade penal no Brasil, dentro de uma reflexão crítica a respeito das formas de controle social que ainda são praticadas pelo Estado na gestão das pessoas tidas como indesejáveis, a fim de atender interesses não declarados. O recorte que se propõe é em relação à construção da ideia do negro como um símbolo de perigo ou até mesmo como um inimigo, um hostil dentro da sociedade que merece os atentos olhos do sistema penal nos espaços urbanos. Com efeito, o legado dessa prática parece estar continuamente a se reinventar a partir da técnica do völkisch (ou popularesco) que consiste, segundo Zaffaroni (2007, p. 57), ${ }^{a}$ em "alimentar e reforçar os piores preconceitos para estimular publicamente a identificação do inimigo da vez", a exemplo do ocorrido às vésperas do ano em que o Rio de Janeiro sediaria os jogos Olímpicos de 2016.

Melhor explicando, na primavera de 2015 o governo do Estado repetiu políticas de segurança pública, na tentativa de controle social absoluto de parte da população selecionada da antiga Capital da República, que remontam à práxis do século XVIII e XIX. 
Naquela ocasião, jovens vindos dos subúrbios cariocas a caminho das praias localizadas na zona nobre da cidade foram retirados a força de dentro do transporte público após agentes do Estado realizarem um procedimento não previsto em lei, vale dizer, em manifesta afronta ao princípio democrático da legalidade, para verificar se os mesmos possuíam quantia em dinheiro suficiente para retornarem ao seu local de partida. Dessa maneira, adolescentes foram detidos e encaminhados ao Centro Integrado de Atendimento à Criança e ao Adolescente, sob a justificativa de não terem dinheiro para a passagem de volta (HERINGUER; BARROS, 2015). ${ }^{a}$ Episódios como esse parecem estar na hipótese que aqui se investiga, ou seja, submetidos a um processo histórico de repetição protagonizado pela seletividade inerente ao sistema penal brasileiro. Assim, em um grupo de 15 jovens considerados "suspeitos da prática de futuros delitos" que foi retirado de um coletivo com destino ao bairro de Copacabana, apenas um era branco, sendo todos os demais 14 com o mesmo perfil: negros e pobres, cerceados do seu direito fundamental à liberdade de locomoção, sem qualquer motivação prevista em lei.

Com a justificativa de entender melhor episódios como o acima citado, a primeira parte do estudo apresenta inquietações acerca da história das ideias políticas e do poder ligadas às questões relacionadas à problemática específica da criminalização seletiva e do controle social na transição política do regime escravocrata para a República, mais precisamente dentro do recorte histórico da virada do século XIX para o XX. O eixo central da problemática da pesquisa pode ser sintetizado com as seguintes perguntas: (i) o sistema penal no Brasil, diante de uma análise histórica, se demonstra como seletivo? (ii) caso positivo, o negro pode ser considerado como um dos alvos dessa seletividade? (iii) como o sistema penal reage às demandas por mais repressão em momentos de fragilidade política, como nas transições de regimes?

A temática das permanências histórico-culturais, que são consideradas como componentes constitutivos da estrutura social, já foi enfrentada por Gizlene Neder (2007), ${ }^{a}$ que considera o estudo do contexto das primeiras décadas da República como capaz de iluminar e refletir sobre o atual momento histórico (NEDER, 2012, p. 271). ${ }^{a}$ A fim de complementar a justificativa da pesquisa, como afirma Gaston Bachelard (1971, p. 18), ${ }^{\mathrm{a}}$ a investigação se situa em mais uma tentativa de resistir e enfrentar o pensamento hegemônico, através de aberturas, fraturas, ranhuras no sólido pensamento absolutista e autoritário que direciona e rege o agir dos sistemas punitivos. Isso será realizado a partir da utilização do espaço acadêmico para confrontar e desarticular a hegemonia das ideias 
que estão constantemente na pauta dos debates políticos sobre a questão da violência no Brasil, na tentativa de formar um pensamento crítico, que possibilite a superação das perspectivas que se propõem a analisar o fenômeno da criminalidade dentro de uma tradição autoritária (CASARA, 2018, p. 157-170)a e, em detrimento do conhecimento, na tentativa de solucionar complexos problemas sociais. Não há nada de pejorativo nessa tentativa de desconstruir se houver o objetivo de se fazer notar que existe uma ciência sob o prisma epistemológico - que tenta romper com o conhecimento comum através de um percurso teórico para a compreensão do fato social, como frisado pelo referido autor.

O objeto conceitual adota as concepções da teoria crítica, preconizadas por Max Horkheimer (1989, p. 144), ${ }^{a}$ e consigna-se que o referencial teórico-metodológico envolve as formulações dos autores inseridos no campo da história do direito e da criminologia crítica, em especial, Gizlene Neder, Gisálio Cerqueira Filho, Eugenio Raul Zaffaroni, Nilo Batista, e Vera Malaguti, com a proposta de se realizar uma investigação intelectual de compreensão daquilo que acontece no tempo presente através da recuperação do processo histórico.

A hipótese é de identificar indícios de permanências históricas na formação ideológica ${ }^{1}$ e na cultura jurídico-política brasileira, para possibilitar a compreensão dos motivos do negro estar entre os alvos preferenciais do sistema penal brasileiro. Ademais, o pensamento crítico é o eixo fundamental para a desconstrução das "verdades" que acreditam no arbítrio estatal, no uso da força e priorizam os interesses das classes dominantes direcionando o projeto criminalizador para as classes dominadas.

No que se refere aos objetivos do presente artigo, a pesquisa irá (i) analisar o contexto histórico do sistema penal durante o regime da escravidão no Brasil e a sua modificação na virada do século XIX para o XX, na conjuntura da passagem do Brasil ao regime republicano declarado em 1889, mais precisamente com as lentes direcionadas para a abolição do regime escravocrata e o cenário urbano na capital brasileira; (ii) o tratamento discriminatório do poder punitivo a determinados seres humanos, mais precisamente dentro do recorte proposto, em relação ao negro no Brasil.

O estudo proposto mostra-se relevante diante das continuidades propostas como solução para antigos problemas de violência e criminalidade no antigo Distrito Federal, que

\footnotetext{
1 O termo ideologia, aqui empregado, "é um conceito pejorativo, um conceito crítico que implica ilusão, ou se refere à consciência deformada da realidade que se dá através da ideologia dominante: as ideias das classes dominantes são as ideologias dominantes na sociedade" (LÖWY, 2006, p. 13).a
} 
recentemente sediou grandes eventos esportivos internacionais, e tratou parte dos cidadãos como seres indesejáveis em determinadas localidades do espaço urbano.

\section{Sistema Penal e Escravismo}

O sistema penal é tradicionalmente compreendido como o complexo normativo e institucional, que decorre da noção de soberania estatal, voltado para a função declarada de garantir uma ordem social justa e igualitária, com a possibilidade do uso de medidas repressivas para a prevenção ou punição de um crime. Dentro da perspectiva crítica adotada pelo trabalho (ZAFFARONI et al., 2011, p. 60-63), ${ }^{a}$ diferente disso, é possível concebê-lo como o conjunto propositalmente caótico (CASARA, 2018, p. 91-105), ${ }^{\mathrm{b}}$ das agências que operam a elaboração da lei penal material no plano abstrato, que permite a punição de um indivíduo diante de determinados comportamentos desviados (criminalização primária); ou que no plano concreto exerce a punição de pessoas que supostamente tenham praticado um ato definido como crime (criminalização secundária). Sob esse prisma, é entendido também como um aglomerado de órgãos estatais, tais como as instituições legislativas, policiais, judiciárias, penitenciárias; e órgãos não estatais, como no caso das universidades, organismos internacionais (Organização das Nações Unidas, OEA- Organização dos Estados Americanos) e, por fim, agências de comunicação social (rádio, televisão e jornais) que operam conforme seus interesses particulares, e de forma descoordenada.

No que diz respeito a essa última característica, é interessante ressaltar que muitas vezes essas instituições estabelecem relações de concorrência entre si, com ganhos não declarados, o que acaba por revelar uma defesa a certos setores socialmente privilegiados. $\mathrm{Na}$ verdade, atuam de acordo com o seu próprio poder, conforme seus próprios interesses setoriais, o que possibilita ao pesquisador identificar e demonstrar falhas e contradições em seu agir cotidiano.

Essas contradições, furos e objetivos não revelados do sistema penal, condicionados por uma tradição autoritária, podem ser observados através da análise de legislações, projetos de lei, números de prisões e presos, discursos de chefes de polícia, dentre outros dispositivos, que merecem uma releitura que possibilite, de forma mais aprofundada, 0 exame dessa estrutura repetitiva, através de uma investigação histórica.

Nessa perspectiva, segundo Casara (2018, p. 91-105), , o significante "justiça" ausenta-se para dar lugar ao significante "poder". Em outras palavras, o valor "justiça" pode 
ser retirado no exercício concreto do sistema/poder penal, um dos principais mecanismos de controle social de pessoas indesejáveis para os donos do poder (FAORO, 1976, p. 45)a político e econômico.

O estudo se voltará agora para a formação do processo histórico que introjetou no senso comum, o afro descendente como representação de um perigo para os integrantes das classes médias da sociedade brasileira.

Nesse sentido, antecedendo um pouco ao recorte historiográfico sugerido, o artigo analisa o período de formação da população negra no Brasil recém descoberto, dentro do projeto de expansão do mercantilismo, que se manifestou pelo ideal de irracionalidade, opressão e exploração por parte dos chamados descobridores. Faoro, ao observar a formação do patronato político brasileiro, constata que a direção do Estado português, ao longo do século XVI, estava configurada para a exploração de toda e qualquer forma de mercancia que propiciasse ganhos para o príncipe - senhor absoluto de todos os lucros e vantagens. Assim, Portugal, "agente econômico extremamente ativo", nas palavras do autor, buscava nas viagens comerciais marítimas novas rendas que a terra já não lhe dava em montante compatível com as suas crescentes necessidades econômicas. O quadro histórico que refletia a realidade do mundo recém encontrado, abundante em recursos naturais e terras férteis, era a ausência de força de trabalho suficiente para a produção do referido cenário em mais valia.

Dentro daquele novo horizonte descoberto de extração de lucros, como se pode observar, o regime escravocrata foi um verdadeiro símbolo do desenho institucional do absolutismo de mercado.

Em que pese o contratualismo moderno ser uma escola que se desenvolveu ao logo dos séculos XVI ao XVIII, a partir das teorizações de Hobbes, Locke e Rousseau (STRECK; MORAIS, 2010, p. 29), a a representação sobre as terras recém descobertas na América brasileira produz o mito de um lugar alheio à história, a luta de classes e ao contrato social, como se o novo continente estivesse situado tão somente dentro de um plano econômico de dilatação do mercantilismo, desconectado do processo histórico civilizatório europeu (CASARA, 2004, p. 22-52). ${ }^{a}$ Assim, a solução eurocêntrica, que concebia os nativos e os negros como seres juridicamente inferiores, era a de submeter estes aos seus interesses patrimoniais através de um particular regime econômico, o da escravidão.

O abuso, traduzido pela ideia de serviço forçado, perdurou para os indígenas até o ano de 1758 quando a Coroa determinou a libertação definitiva dos mesmos, prosseguindo 
com a exploração brutal dos negros que, comprados na África entre os anos de 1550 e 1855, chegaram ao número de quatro milhões, em sua grande maioria, jovens do sexo masculino. Calcula-se que durante a primeira metade do século XVII, nos anos do apogeu da economia do açúcar, o custo de aquisição de um escravo era amortizado entre treze e dezesseis meses de trabalho, e mesmo depois de uma grande alta nos preços de compra de cativos, após o ano de 1700, um escravo se pagava em trinta meses (FAUSTO, 2015, p. $45-49){ }^{\text {a }}$

Aparece aí, como observa Chauí (2000, p. 27), ${ }^{a}$ a identidade nacional associada à violência branca e a alienação negra, isto é, duas formas de consciência definidas por uma única instituição - a escravidão, que pode ser entendida como um processo de apropriação do trabalho do outro, da dominação do corpo, do trabalho e do tempo do ser humano através da força bruta. Em outras palavras, desde os primórdios estão sedimentadas no substrato social brasileiro as camadas estamentais, mencionadas por Faoro, formadas por integrantes que pensam e agem conscientes de pertencer a um círculo elevado e qualificado para operar e se manter no exercício do poder.

Consectário dessa ideia, a reflexão crítica tem negligenciado algumas considerações sobre sistema penal durante o escravismo colonial, segundo Nilo Batista (2007). ${ }^{a}$ Para o autor é necessário entender-se que dentro do regime da escravidão a pena pública era executada de forma diversa, uma vez que o vassalo estava inteiramente "submetido a um poder punitivo privado, no Brasil jamais regulado, que se comunicava com o poder punitivo público", no qual cabia ao senhor - proprietário de outro ser humano - o direito privado de executar sanções penais aplicadas aos escravos em casos de transgressões ao ordenamento então vigente, vale dizer, o controle da execução penal estava no âmbito privado.

Os fundamentos jurídicos desse particular poder de penalizar eram extraídos de diversos comandos do Código Criminal do Império do Brasil, a exemplo do disposto no artigo 60 do citado diploma que estabelecia que, salvo as penas de morte ou galés, que seriam efetivadas pelo Estado, os condenados escravos teriam todas as demais sanções penais convertidas em açoites, que após a execução, seriam entregues ao senhor que se obrigava a trazer o apenado com um ferro, pelo tempo e maneira que o juiz designasse. $O$ dispositivo, em sua parte final, limitava em 50 açoites diários a máxima intensidade da pena.

No que tange ao direito sobre o encarceramento dos negros, segundo José Pascal de Mello Freire, citado pelo autor (BATISTA, N., 2007), ${ }^{\text {a a }}$ mesma legislação, em seu artigo 
14, §6º previa como causa justificante à caracterização do crime de cárcere privado, o senhor que castigasse o cativo e o prendesse em casa, de modo que a brutalidade do ato não extrapolasse o direito de correção doméstica (FRANCO; NUCCI, 2011, p.135). ${ }^{a}$ Ou seja, já existia a criminalização da conduta de segregar a liberdade de outra pessoa, contudo, a norma penal abria uma exceção no caso do senhor que praticasse essa ação.

É perfeitamente constatável, portanto, a predominância de um poder público sancionatório executado de forma desregulada e não fiscalizada pelos senhores contra seus escravos. Essa barbaridade institucionalizada, segundo Neder (2007, p. 148-150), ${ }^{b}$ estava atrelada ao protótipo jurídico-penal iluminista, formado na virada do século XVIII para o XIX, como uma realidade no império luso-brasileiro e "reflete a vinculação teórica, metodológica e ideológica do absolutismo ilustrado, mesmo após a emancipação política no Brasil”, em 1822. Essa proximidade retrata a noção de existência de uma formação histórica luso-brasileira que trouxe marcas da religiosidade cristã, a exemplo do que acontecia no Tribunal do Santo Ofício, e da cultura jurídica conimbricense que atuam como uma permanência cultural bastante marcante. Em outras palavras, as ideias ilustradas decorrentes do processo histórico de secularização defendidas, principalmente, na França e Inglaterra tiveram penetração limitada no império lusitano e, consequentemente, no Brasil, essencialmente em razão das resistências da Igreja ao advento da razão humana, o que colocava em xeque dogmas cristãos, por sua vez alinhados aos interesses da Coroa lusitana.

O aspecto que aqui se sublinha, é que o iluminismo jurídico penal luso-brasileiro tinha uma nítida contradição entre o rol de direitos e garantias fundamentais, elencados nos incisos do artigo 179 da Constituição de 1824, dentre os quais estavam elencados a garantia da isonomia, da legalidade; e os privilégios da nobreza e o regime de escravidão que sequer eram mencionados naquela Carta. Não pode ser esquecido que, embora não fizesse menção expressa a escravidão, a citada Carta se curvava a mesma "sob a fórmula circunloquial de garantir 'o direito de propriedade em sua plenitude' (art. 179, inciso XXII)" (BATISTA, N., 2016, p. 33). ${ }^{a}$

O Código Criminal de 1830, que viabilizava esse sistema, teoricamente articulava de um lado as ideias liberais de Beccaria e, de outro, as tentativas de controle penal absoluto e punição privada sobre os escravos, que pode ser explicado, segundo Neder, pelas concepções encadeadas pelas reformas pombalinas durante o século XVIII, na qual instaurou-se um processo de modernização conservadora em Portugal, em que é possível 
destacar "a presença de uma retórica formalmente ilustrada, mas em defasagem com a prática efetiva" (NEDER, 2007, p. 106-116). ${ }^{c}$

Grande exemplo disso era o tratamento dispensado ao princípio da reserva legal, ${ }^{2}$ previsto em ambos os documentos mencionados, e com toda a sua significação política de ruptura com as práticas absolutistas, mas que nesse recorte histórico não passava de mera verborragia. Nilo Batista (2016, p. 34) ${ }^{\mathrm{b}}$ demonstra que à revelia da citada norma, o Código de Processo Penal de 1832 possibilitava ao juiz de paz cominar penas de multa, prisão até 30 dias ou internação por 3 meses em casa de correção ou oficinas públicas, aos suspeitos de pretensão de cometer algum crime, caso não cumprissem o termo de segurança que eram obrigados a assinar, dentre outros exemplos de afronta à legalidade, sendo certo que essa possibilidade, anos adiante, em 1841, foi transferida para chefes de polícia, delegados e subdelegados.

Dentro desse regime institucional é importante lembrar que a vedação a pena de morte era anunciada como se fosse uma grande evolução, pautada pelas ideias revolucionárias e anticlericais inspiradas na Revolução Francesa, em relação às Ordenações Filipinas, anteriormente vigentes que constituíram o eixo da programação criminalizante de nossa etapa colonial tardia, sem embargo da subsistência paralela do direito penal doméstico que o escravismo necessariamente implica (BATISTA, N., 2016, p. 22).

A seletividade penal confirmava que a isonomia constitucional somente era prevista no plano abstrato, na medida em que abria uma exceção a vedação da pena capital. Essa ressalva prevista em lei, que possibilitava a execução oficial de outro ser humano, estava prevista para os casos de crime de insurreição de escravos contra senhores, previsto no artigo 113 do CCr 1830, que previa como conduta típica a reunião entre 20 ou mais escravos para conseguirem a liberdade por meio de força (ZAFFARONI et al., 2011, p. 436440). ${ }^{b}$ Em outras palavras, o Código Imperial permitia a pena de morte apenas para àqueles vulneráveis ao regime econômico escravagista. Significa dizer que houve o avanço da razão em relação à vedação legal a pena capital, com exceção aos crimes de insurreição eventualmente praticados por escravos, que segundo a ordem vigente deveriam estar obedientes e submissos aos seus senhores.

Dentro desse quadro de contradições entre os ideais revolucionários iluministas e o regime de escravidão, estava a primeira codificação penal publicada no Brasil, o já citado

\footnotetext{
2 Não há crime sem lei anterior que o defina, nem pena sem prévia cominação legal.
} 
Código de 1830. No plano teórico essa legislação ainda é colocada como um avanço em relação às Ordenações Filipinas, contudo, no plano da efetividade, estava alinhada aos interesses econômicos e, principalmente, atendendo ao clamor das elites.

\section{A programação criminalizante direcionada ao inimigo do Império no Brasil}

O fiasco do projeto liberal pode ser explicado pelo fato de estar no poder aquele estamento mais "diretamente interessado na conservação do regime: os proprietários rurais, que se tornam sob o império a força política e socialmente dominadora" (BATISTA, N., 2016, p. 33). ${ }^{d}$ Dessa maneira, a aplicabilidade da primeira codificação penal brasileira (CCr 1830) estava diretamente vinculada às ideias de identificação do inimigo público que causava medo a população, vale dizer, àqueles que dentro do pessimismo agostiniano eram identificados como os predestinados ao mal. É essa a referência criminológica que se tem em relação ao Código de 1830, ou seja, a história do medo no Brasil e seu impacto na vida social e política, já examinado por Vera Malaguti Batista (2003) em sua obra O medo na cidade do Rio de Janeiro. A autora mostra que esse sintoma social está diretamente relacionado aos receios populares que dizem respeito às insurreições de escravos e à criminalidade nutrida pela pobreza, que sempre desempenharam e realizam até os dias atuais, um verdadeiro protagonismo na sociedade brasileira.

Ao trabalhar a história ideológica do controle social no Brasil atual, Neder $(2007)^{d}$ denuncia o arbítrio das fantasias absolutistas de controle social policial absoluto na subjetividade brasileira. Na Capital do Império no século XIX, a quantidade de negros na corte passou a deixar seus integrantes receosos. Segundo Casara (2004, p. 42), ${ }^{b}$ trata-se do medo do haitianismo, que pode ser entendido como toda e qualquer revolução negra. $O$ então chefe de polícia - Eusébio de Queiroz - afirmou que a escravidão seria efetivamente um limite à recepção das políticas mais modernas de policiamento urbano, de corte liberal, tendo em vista a presença de escravos e libertos no mesmo espaço urbano. Para ele, o uso indiscriminado de chapéus ou de sapatos, por exemplo, ampliava a dificuldade em se implementar um policiamento voltado a tutela da cidadania, sendo a escravidão o motivo que justificaria "a não adoção plena da postura psicoafetiva e política da nova ciência de polícia” (NEDER, 2007, p. 183-184). e Queiroz apontou que o único plano viável para o policiamento do Rio de Janeiro seria o confinamento dos negros nas fazendas, a forte repressão e controle policial no seu deslocamento para os centros urbanos. Dentro dessa ideia, a título de exemplo, pode ser citada a disposição da câmara municipal da Vila de 
Maracás que punia com 8 dias de prisão, a mera deambulação de escravo, após 21 horas sem bilhete de autorização do seu senhor (BATISTA, N., 2016, p. 36). ${ }^{e}$

É inegável que o poder punitivo discriminava os escravos e lhes conferia tratamento não correspondente à condição de pessoas humanas, pois os considerava como entes daninhos ou perigosos. Assim, dentro do que foi denominado por Zaffaroni (2007, p. 22$25)^{\mathrm{b}}$ como o inimigo no direito penal, identifica-se a origem no tratamento diferenciado e discriminatório que determinados modelos de estado adotaram ao longo da história. O tema foi trabalhado, segundo o autor, pelo teórico do Estado absoluto Carl Schmitt ao afirmar que inimigo não é qualquer cidadão que venha a transgredir normas penais incriminadoras, mas sim o outro, o estrangeiro (hostis alienígena), aquele que incomoda o poder, os insubordinados que inspiram desconfiança e, por seguinte, merecem tratamento diferenciado através de uma atuação seletiva do sistema penal.

Em que pese o ano de 1850 ter sido marcado pela proibição do tráfico internacional de escravos, o tráfico interprovincial continuava a ocorrer para sustentar a cultura do café no Sudeste. Sedimentado na ideologia estamental, o lento avanço rumo ao fim desse regime de exploração humana teve uma tímida evolução por meio da chamada Lei do ventre livre de 1871 (BRASIL, 1871), ${ }^{a}$ isto é, o primeiro passo rumo à transição para o regime de liberdades dos escravos. Essa legislação, como explica Fausto (2015, p. 186189), ${ }^{b}$ na verdade, não demonstrou uma evolução significativa em relação à problemática, uma vez que em termos práticos aumentou o índice de mortalidade infantil em razão do descaso dos proprietários em relação aos recém-nascidos, especialmente em relação àqueles do sexo feminino. E "como a lei é do ano de 1871, é de se concluir que poucos foram os filhos de escravas que foram beneficiados com a liberdade ao longo desses dezessete anos que os separaram da promulgação da Lei Áurea" (HOGEMANN, 2012, p. 48). ${ }^{\mathrm{a}}$

Passo seguinte, ainda segundo Hogemann (2012), ${ }^{b}$ dentro da ideia de uma transição lenta e gradual, veio com a denominada Lei dos Sexagenários (BRASIL, 1885)a que assegurava a libertação para as pessoas naquela condição que completassem sessenta anos de vida. Já os que contassem com idade entre sessenta e sessenta e cinco anos deveriam, conforme as disposições transitórias da legislação, prestar mais três anos de serviços e, posteriormente, poderiam ser libertados, sendo assegurada uma indenização aos senhores proprietários que seria viabilizada a partir da criação de um fundo de emancipação, diante de seu prejuízo de cunho patrimonial. 
Por fim, quase três anos depois foi abolida a escravidão no Brasil, por meio da Lei 3353 de 13 de maio de 1888 que somente foi submetida à apreciação após um significativo estudo sobre os impactos econômicos, além de uma avaliação específica em termos de segurança pública. Observa-se ainda que, ao invés desse momento histórico receber a cunhagem de conquista popular contra o poder constituído - como um imperativo da secularização, a princesa Isabel deu ao ato um caráter de dádiva bondosa (CASARA, 2004, p. 22-52).c

Em suma, mais de meio século após o êxito do abolicionismo no Chile e na Bolívia, o Brasil extingue a escravidão no final do século XIX, de sorte que rapidamente a nova República proclamada tratou de tomar providências quanto ao "fator risco" da transição do regime escravocrata para o sistema de liberdades.

Em que pese a reflexão aqui proposta, a historiografia tradicional do direito repressivo costuma se referir a esse momento político - publicação do CCr 1890 - como uma pseudo evolução legislativa que teria abolido a pena de morte e suprimido as sanções perpétuas e infames, tendo-as substituído pela prisão celular. Em crítica a essa posição que enfoca em grande parte a perspectiva positivista, Neder (2012, p. 71) esclarece que boa parte da análise negligencia a problemática histórico-social, e adota uma visão evolucionista pautada em uma ideia de progresso do sistema penal. Em outras palavras, ao invés de tratar a tardia libertação daqueles seres humanos com políticas públicas de educação, inclusão no mercado de trabalho, moradia, saúde, entre outras, a medida tomada foi a edição do decreto no 847, isto é, o Código Penal de 1890 (BRASIL, 1890). ${ }^{\text {a }}$

\section{O Código de 1890 como mecanismo de transição de regimes políticos}

Abolida a escravidão e instaurada a República, é inevitável o enfrentamento da problemática relativa às transições de regimes políticos que, segundo Neder $\left(2012\right.$, p. 269) ${ }^{c}$ "estão a indicar não apenas rupturas, mas também permanências e continuidades que devem ser anotadas”. A partir dessa marcação, é imprescindível o enfrentamento do tema das políticas públicas destinadas ao tratamento do chamado legado autoritário, na qual são desenvolvidas formas de confrontação àquele passado não distante que se mostra predisposto a promover continuidades. Em que pese a ocorrência de uma ruptura política e institucional, a fim de que se fortaleçam as novas instituições em conformidade com o regime político que se pretende inaugurar, são imprescindíveis mecanismos destinados a evitar as atrocidades do passado (TEITEL, 2005). ${ }^{a}$ Para Elster (2004), ${ }^{a}$ as medidas relativas 
às arbitrariedades praticadas pelo regime ancião podem ser definidas como o processo de julgamentos, expurgos e reparações que tomam lugar pelos desvios perpetrados pelos atores políticos do regime anterior. ${ }^{3}$ Podem ser mencionados em relação a problemática, o julgamento de Luís XVI após o processo revolucionário francês no fim do século XVIII, assim também como os julgamentos de Nuremberg no pós II Guerra.

No Brasil, no que tange a superação do regime ditatorial de 1964-1985 e a reinauguração da ordem democrática, foram adotadas diversas medidas em relação ao ancién regime. Podem ser aqui citadas a criação da Comissão de Mortos e Desaparecidos Políticos (Lei 9.140/95 [BRASIL, 1995]); a a Comissão de Anistia (Lei 10.559/02 [BRASIL, 2002]); ${ }^{a}$ o ajuizamento da ADPF (Ação de Descumprimento de Preceito Fundamental) no 153, com a finalidade de que o STF desse a Lei de Anistia (Lei 6.683/79 [BRASIL, 1979]) a interpretação conforme a Constituição, de modo a declarar que a anistia concedida pelo citado diploma não se estendesse aos crimes comuns praticados pelos agentes da repressão, o que viabilizaria - em tese - uma futura persecução penal contra os responsáveis pelas atrocidades ocorridas naquele regime; além da criação da Comissão Nacional da Verdade (Lei 12.528/11 [BRASIL, 2011ª]). ${ }^{4}$

Sob o prisma do fim da escravidão, com a consequente declaração da República (1889), as medidas que foram tomadas no Brasil pareciam destinadas a manutenção do mesmo status quo anterior, vale dizer, um estado de segregação e repressão seletiva de parte da população. Doravante, a grande preocupação era garantir que os negros recém libertos fossem submetidos a um controle social penal absolutista após a inauguração da República, em uma nova onda de desconfiança generalizada com os afro-brasileiros.

Os parlamentos no Brasil eram predominantemente compostos por fazendeiros escravocratas e seus filhos, educados em profissões liberais, que monopolizavam a política, elegendo candidatos, dominando os ministérios, e as posições de mando e desmando, como afirma Sérgio Buarque de Holanda (2014, p. 86). ${ }^{a}$ Foi assim que no mesmo ano de 1888, quando foi finalizado aquele modelo econômico, a Câmara dos Deputados já votava um projeto de criminalização da vadiagem, com previsão de penas privativas de liberdade até 3 anos para reincidentes, em manifesta ausência de ruptura com

\footnotetext{
3 "Transitional justice is made up of the process of trials, purges, and reparations that take place after the transition from one political regime to another" (ELSTER, 2004, p. 1-3). ${ }^{\mathrm{b}}$

${ }^{4} \mathrm{O}$ direito penal não é imprescindível para a justiça de transição, muito embora já tenha sido utilizado com essa finalidade. Quem sustenta a tese em contrário, o faz embasado no antigo mito da função preventiva da pena e na crença da bondade do poder punitivo estatal, conforme Salo de Carvalho. O que não pode ser esquecido é o fato de o sistema penal ter sempre sido objeto de manipulação dos próprios regimes autoritários (CRUZ, 2015). a $^{\text {a }}$
} 
o regime jurídico do CCr 1830. Esse projeto repressivo foi elaborado na tentativa de apaziguar os medos das elites com receio das hordas de libertos que perambulariam pelas estradas furtando e surrupiando propriedades no campo; e na cidade, os bandos de capoeiras e todos aqueles pobres desocupados não admitidos na indústria (BATISTA, N., 2016, p. 63), ${ }^{\dagger}$ dentro do processo de ideologização que acompanha a passagem ao capitalismo.

Com as portas das senzalas abertas, a ocupação dos espaços públicos pelos negros passou a produzir uma sensação generalizada de caos, o que reafirmou o sintoma social, que dava o fundamento para a repressão a ociosidade. Dentro do período de passagem ao capitalismo, a preocupação se dava com as taxas de incapazes, de mendigos, de negros recém-libertos, e dos demais considerados, por essa concepção, como anormais que dificultam e oneram a parte produtiva da sociedade. Assim, "no discurso deste novo sistema penal, a inferioridade jurídica do escravismo será substituída por uma inferioridade biológica", ou seja, enquanto naquela era possível reconhecer-se uma mera decisão de poder, nesta, existia a necessidade de uma demonstração científica (BATISTA, N., 2016, p. 64), ${ }^{g}$ na linha daquilo que posteriormente foi afirmado por Nina Rodrigues $(1894 / 1940)^{\mathrm{a}}$ em seu livro de 1894, As raças humanas e a sua responsabilidade penal no Brasil, onde tentou buscar a relação biológica entre crime e raça. Ao considerar a desigualdade racial no Brasil, de acordo com as diferenças culturais de cada raça, o sistema penal brasileiro precisaria, segundo o autor, de uma imputabilidade penal também desigual. Assim, o autor acabou por defender a relatividade do conceito de crime fundamentada nos pressupostos das raças superiores (civilização ariana no Brasil) versus inferiores (afrodescendentes) (NEDER, 2012, p. 141-143). ${ }^{d}$ Essa ideia, além de estar afinada à concepção agostiniana de predestinação ao mal, alinha-se também a vertente da Escola Positiva Lombrosiana, com a tese do criminoso nato.

Pode-se afirmar que no sistema penal republicano, inaugurado pelo Código de 1890, o racismo tem uma explicável permanência no discurso criminal republicano para realizar a função de permitir um corte higienizador na população administrada e ressaltar que a neutralização dos inferiores é que deixará a vida social mais segura. O sintoma social das elites em relação ao negro recém liberto se manifestou de tal forma no cenário brasileiro a ponto de, após a abolição da escravidão em 1888 e a declaração da República em 1889, o poder constituído ter entendido que a edição de uma lei penal incriminadora ser mais importante do que a promulgação de uma Constituição, o que somente se deu em 1891. 
Sem a pretensão de elaborar uma análise dogmática do CCr 1890, uma vez que a preocupação do artigo é em relação ao processo histórico de formação da seletividade penal, com um enfoque particular em relação à construção da ideia do negro como inimigo, a pesquisa passa ao estudo de alguns aspectos desse código que tinham aplicabilidade principalmente sobre os ex-escravos. Assim, o Código dividia-se em 4 livros, sendo o primeiro deles intitulado Dos crimes e das penas; o segundo tratava Dos crimes em espécie; o terceiro Das contravenções em espécie e; por fim, o último com a previsão Das disposições gerais.

A imputabilidade penal começava aos 9 anos de idade, desde que se verificasse que o réu tinha discernimento; e dos 14 anos em diante, sem a necessidade de qualquer análise, conforme o artigo 27, $\S \S 1^{\circ}$ e $2^{\circ}$ daquele diploma legal (FRANCO; NUCCI, 2011, p. 193). ${ }^{\text {b }}$ Assim, um menor de 14 anos, e maior de 9 anos de idade com discernimento, poderia ser recolhido em estabelecimentos disciplinares industriais, pelo tempo que o magistrado entendesse, contanto que o recolhimento não excedesse a idade de 17 anos, conforme o disposto no artigo 30. Assim, o jovem que cometera uma conduta desviada, considerada como crime aos 9 anos de idade, ao sair da prisão fábrica com 17 anos, teria vivido 8 anos, ou seja, quase a metade de sua vida em um estabelecimento disciplinar industrial.

No que tange às sanções penais, estavam previstas as penas de prisão celular; banimento - posteriormente extinta pela Constituição de 1891; reclusão - somente para delitos políticos; prisão com trabalho - que seria cumprida em penitenciárias agrícolas ou presídios militares; prisão disciplinar; interdição, suspensão ou perda de emprego público; e multa, conforme o artigo 43.

Chama atenção, nesse contexto, a situação do ex-escravo - recém liberto do regime de trabalho obrigatório - uma vez que o Código de 1890 também criminalizava o simples estado ou condição dessas pessoas ao fazer a previsão de crimes com condutas sem qualquer potencial lesivo a bens jurídicos. Significa dizer que o estado que foi condescendente durante séculos com escravidão, após abolir o regime, não permitia a simples diversidade cultural.

Por conseguinte, foi criminalizada pelo mesmo Código a conduta de "fazer nas ruas e praças públicas exercícios de agilidade e destreza corporal conhecidos pela denominação de capoeiragem", prevista no artigo 402, com a possibilidade de a pena chegar ao patamar de 3 anos, em caso de reincidência, a ser executada em colônias penais em ilhas marítimas ou nas fronteiras dos territórios nacionais. 
Na ação policial daquela época, Neder $\left(2012\right.$, p. 145) ${ }^{\mathrm{e}}$ retrata o apoio incondicional recebido pelo chefe de polícia Sampaio Ferraz pela mídia, na política de perseguição aos capoeiras que quando presos, conforme as sanções acima enumeradas, eram enviados para cumprir penas na distante Ilha de Fernando de Noronha, em nítida política de higienização da Capital Federal em um verdadeiro apartheid à brasileira.

Outra criminalização que recaía especialmente sobre os afro-brasileiros era a previsão contida no artigo 399, que determinava a pena de prisão celular de 15 a 30 dias, para a conduta de vadiagem. Nesse sentido, previa o parágrafo primeiro deste dispositivo que na mesma sentença em que o juiz condenasse o infrator como vadio, ou vagabundo, seria o infrator obrigado a assinar um termo no qual ficava obrigado a tomar ocupação lícita dentro de 15 dias, contados a partir do fim do cumprimento da pena. Interessante notar que a seletividade penal mais uma vez ficaria exposta pelo teor do artigo 400 do mesmo Código que previa como causa de extinção da punibilidade, a prova por parte do condenado que comprovasse renda bastante para a sua subsistência. Ou seja, para o escravo recém liberto e condenado por vadiagem, se não cumprisse a obrigação de tomar ocupação lícita no prazo de 15 dias, poderia agora ser preso pelo prazo de até 3 anos, a serem cumpridos também em ilhas marítimas ou na fronteira do território nacional; ao contrário daquele que, pertencente a uma classe mais abastada e que comprovasse renda, teria a sua punibilidade extinta.

A pesquisa empírica feita por Neder (2012, p. 292) revela que no ano 1892, ou seja, 2 após a publicação do Código de 1890, das 655 detenções levantadas das análises dos registros dos relatórios dos chefes de Polícia e dos ministros da Justiça, e dos Livros da Casa de Detenção, guardados no Arquivo Público do Estado do Rio de Janeiro; 229 foram motivadas por distúrbio/algazarra relativos à prática de batuques relacionados aos cultos religiosos afro brasileiros, de modo a mais uma vez caracterizar a seletividade da ação repressora.

E a primeira República não parou por aí com a sua programação criminalizante, uma vez que através de outras leis penais o sistema penal continuaria a atingir os seus alvos sociais preferências. Dessa maneira, o furto de gado que se tornou, para utilizar a expressão de Nilo Batista (2016, p. 77), ${ }^{\text {h }}$ um "pesadelo do latifúndio após a abolição", foi modificado pelo decreto $\mathrm{n}^{\circ} 121$ de 1892 para se tornar crime de ação penal pública, punido com a mais elevada pena cominada ao furto e se tornou delito inafiançável pela edição da lei no 628 de 1899 (BRASIL, 1899). ${ }^{\text {a }}$ 
Por fim, pensar em sistema penal é refletir sobre as suas contradições, furos e objetivos não declarados, que merecem uma análise que possibilite, de forma mais aprofundada, o exame dessa estrutura repetitiva. Esta aponta para a possibilidade de identificá-lo como sintomático, ${ }^{5}$ diante da análise de suas falas, dos textos das leis repressoras, do clamor midiático por mais repressão, dos discursos de chefes de polícia notadamente direcionados a determinado alvo.

Essa estrutura repetitiva vai ao encontro da análise aqui proposta do sistema penal, na qual foi possível perceber que este atua historicamente de forma seletiva, no que diz respeito a escolha de seus alvos sociais. Além disso, funciona de forma sintomática, no que diz respeito as suas formas de atuação diante das demandas por manutenção da ordem social, sempre reagindo com a mesma estrutura sintomática seletiva, através de continuidades históricas e sem rupturas institucionais, em que pese o fim da escravidão e o advento do liberalismo.

\section{Considerações finais}

Através da investigação histórica aqui realizada, é possível compreender de uma melhor forma episódios como o ocorrido nas vésperas dos grandes eventos realizados no Rio de Janeiro, quando entre um grupo de 15 jovens presos, sem qualquer motivação legal, 14 desses eram negros e pobres, uma vez que a repressão penal é historicamente direcionada a estes. Assim, dentro do estudo dos aspectos de rupturas e continuidades, é possível concluir que aquelas somente ocorreram em um aspecto formal nas transições de regimes políticos, como no caso aqui estudado da virada do século XIX para o XX. No que diz respeito às ideologias de controle social é possível perceber as continuidades históricas de repressão penal seletiva que continuam presentes até os dias atuais, em verdadeiros espetáculos que associam a ideia de justiça ligada a repressão e ao uso da força, em prejuízo de conquistas civilizatórias fundamentais.

\footnotetext{
${ }^{5} \mathrm{~A}$ ideia de um sistema penal brasileiro sintomático será melhor desenvolvida estudo posterior. Esta estrutura pode ser compreendida transversalmente pela subversão freudiana do sujeito, através do advento do inconsciente, quando foi estabelecido um novo estatuto para o sintoma, distinto do determinado pela medicina. O sintoma deixou de ser efeito de um mal, ou seja, o sinal de uma doença, em que o médico diagnostica e direciona para a cura e passa a possuir uma função fundamental, que o possibilita ser lido enquanto formação significante do inconsciente e, nessa condição, uma mensagem a ser decifrada. A direção apontada por Freud não é no sentido da busca de uma solução, vale dizer, com o objetivo de por fim ao sintoma, mas sim, para redimensioná-lo, ao custo da rearticulação do sujeito em outro posicionamento frente a tragédia edípica (GARCIA-ROSA, 2013, p. 168-177). ${ }^{\text {a }}$
} 
Ademais, o percurso trilhado pelo trabalho permite perceber que existem sim alvos preferenciais do sistema penal brasileiro, o que autoriza caracterizá-lo como seletivo e, dentro dessa realidade, o negro pode ser considerado como de seus principais alvos.

Isso ficou demonstrado pelas diferentes formas de punição a que o negro foi submetido desde o advento da primeira codificação penal brasileira, publicada durante a escravidão, que foi anunciada como uma grande inovação liberal justamente por não mais permitir pena de morte. Contudo, a única exceção a qual caberia a aplicação da sanção capital era exatamente na hipótese dos negros se rebelarem contra seus senhores, problemática essa que se encontra localizada dentro da discussão sobre a modernidade e o atraso cultural da sociedade brasileira.

Com o fim da escravidão, já no ano seguinte foi publicada uma nova legislação penal, agora com o objetivo de perseguir ex-escravos e seus descendentes, sendo certo que estes, poderiam ser presos desde a tenra idade dos 9 anos de idade e serem submetidos a punição em estabelecimentos penais industriais até os 17 anos de idade. Já aqueles recém libertos do regime de obediência, submissão e trabalhos forçados, agora poderiam ser apenados com sanções de prisão com trabalho forçado em penitenciárias agrícolas ou presídios militares; ou enviados para cumprir penas na distante llha de Fernando de Noronha.

Dessa forma, o sistema penal de 1890 pode ser considerado como uma modernização conservadora, que tinha no racismo uma explicável permanência, diante dos receios das elites brasileiras assustadas com as hordas de recém-libertos a perambularem pelas ruas, sem o controle social penal absolutista.

Assim sendo, o sistema penal brasileiro pode ser definido como sintomático, uma vez que foi possível perceber a sua histórica estrutura repetitiva, de manutenção da repressão penal direcionada ao negro. Por fim, a escravidão é aqui entendida como o sintoma do sistema penal brasileiro.

\section{Referências}

BACHELARD, Gaston. A Epistemologia. São Paulo: Martins Fontes, 1971. ${ }^{\mathrm{a}}$

BATISTA, Nilo. Pena pública e escravismo. In: NEDER, Gizlene (Org.). História \& direito: jogos de encontros e transdisciplinaridade. Rio de Janeiro: Revan, 2007. p.33-62. a, b

BATISTA, Nilo. Apontamentos para uma história da legislação brasileira. Rio de Janeiro: Revan, 2016. ${ }^{a, b, c, ~ d, ~ e, ~ f, ~ g, ~ h ~}$ 
BATISTA, Vera Malaguti. O medo na cidade do Rio de Janeiro: dois tempos de uma história. 2. ed. Rio de Janeiro: Revan, 2003. ${ }^{a}$

BRASIL. Presidência da República. Casa Civil. Subchefia para Assuntos Jurídicos. Lei $n^{\circ}$ 2.040, de 28 de setembro de 1871. Declara de condição livre os filhos de mulher escrava que nascerem desde a data desta lei, libertos os escravos da Nação e outros, e providencia sobre a criação e tratamento daquelles filhos menores e sobre a libertação annaul de escravos..... 1871.

http://www.planalto.gov.br/ccivil_03/leis/lim/LIM2040.htm. Acesso em: 20 mar. 2018. ${ }^{\text {a }}$

BRASIL. Congresso Nacional. Senado Federal. Secretaria-Geral da Mesa. Secretaria de Informação Legislativa. Lei n. 3270 - de 28 de setembro de 1885. Regula a extincção gradual do elemento servil. 1885. Disponível em: http://legis.senado.leg.br/legislacao/ListaTextoSigen.action?norma=545046\&id=14377125 \&idBinario=15779572\&mime=application/rtf. Acesso em: 22 mar. 2018. ${ }^{a}$

BRASIL. Presidência da República. Casa Civil. Subchefia para Assuntos Jurídicos. Decreto $n^{\circ}$ 847, de 11 de outubro de 1890. Promulga o Codigo Penal. 1890. Disponível em: http://www.planalto.gov.br/ccivil_03/decreto/1851-1899/D847.htm. Acesso em: 23 mar. 2018. ${ }^{\mathrm{a}}$

BRASIL. Presidência da República. Casa Civil. Subchefia para Assuntos Jurídicos. Lei $n^{\circ}$ 628, de 28 de outubro de 1899. Amplia a acção penal por denuncia do Ministerio Publico, e dá outras providencias. 1899. Disponível em: http://www.planalto.gov.br/ccivil_03/leis/1851-1900/L628-1899.htm. Acesso em: 25 mar. 2018. ${ }^{\mathrm{a}}$

BRASIL. Presidência da República. Casa Civil. Subchefia para Assuntos Jurídicos. Lei $n^{\circ}$ 6.683, de 28 de agosto de 1979. Concede anistia e dá outras providências. 1979. Disponível em: http://www.planalto.gov.br/ccivil_03/leis/L6683.htm. Acesso em: 23 mar. 2018. ${ }^{a}$

BRASIL. Presidência da República. Casa Civil. Subchefia para Assuntos Jurídicos. Lei $n^{\circ}$ 9.140, de 04 de dezembro de 1995. Reconhece como mortas pessoas desaparecidas em razão de participação, ou acusação de participação, em atividades políticas, no período de 2 de setembro de 1961 a 15 de agosto de 1979, e dá outras providências. 1995. Disponível em: http://www. planalto.gov.br/ccivil_03/LEIS/L9140.htm. Acesso em: 23 mar. 2018. ${ }^{a}$

BRASIL. Presidência da República. Casa Civil. Subchefia para Assuntos Jurídicos. Lei $n^{\circ}$ 10.559, de 13 de novembro de 2002. Regulamenta o art. 8 do Ato das Disposições Constitucionais Transitórias e dá outras providências. 2002. Disponível em: http://www.planalto.gov.br/ccivil_03/LEIS/2002/L10559.htm. Acesso em: 24 mar. 2018. ${ }^{a}$

BRASIL. Presidência da República. Casa Civil. Subchefia para Assuntos Jurídicos. Lei no 12.528, de 18 de novembro de 2011. Cria a Comissão Nacional da Verdade no âmbito da Casa Civil da Presidência da República. 2011. Disponível em: http://www.planalto.gov.br/ccivil_03/_Ato2011-2014/2011/Lei/L12528.htm. Acesso em: 24 mar. 2018. ${ }^{a}$

CASARA, Rubens. Interpretação Retrospectiva: Sociedade Brasileira e Processo Penal. Rio de janeiro: Lúmen Júris, 2004. ${ }^{a, b, c}$ 
CASARA, Rubens. Estado Pós-Democrático: neo-obscurantismo e gestão dos indesejáveis. Rio de Janeiro: Civilização Brasileira, 2018. ${ }^{a, b, c}$

CHAUÍ, Marilena. Brasil: mito fundador e sociedade autoritária. 7. impr. São Paulo: Fundação Perseu Abramo, 2000. ${ }^{a}$

CRUZ, Eugeniusz. Justiça de transição no Brasil: análise crítica da persecução penal dos agentes da ditadura. Curitiba: Juruá, 2015. ${ }^{a}$

ELSTER, Jon. Closing the books: transitional Justice in historical perspective. Nova lorque: Cambridge University, 2004. ${ }^{\text {a, b }}$

FAORO, Raymundo. Os donos do poder: formação do patronato político brasileiro. 3. ed. Porto Alegre: Globo, 1976. v. 1. ${ }^{\mathrm{a}}$

FAUSTO, Boris. História do Brasil. São Paulo: Universidade de São Paulo, 2015. a, b

FRANCO, Alberto Silva; NUCCI, Guilherme de Souza (Coord.). Códigos Penais Históricos do Brasil. In: Doutrinas Essenciais de Direito Penal. São Paulo: Revista dos Tribunais, 2011. v. 9 , p. $185-263 .^{a, b}$

GARCIA-ROSA, Luiz Alfredo. Freud e o inconsciente. Rio de Janeiro: J. Zahar, 2013. ${ }^{a}$

HERINGUER, Carolina; BARROS, Rafaella. PM aborda ônibus e recolhe adolescentes a caminho das praias da Zona Sula do Rio. Jornal Extra, Rio de Janeiro, 24 ago 2015. Disponível em: https://extra.globo.com/noticias/rio/pm-aborda-onibus-recolheadolescentes-caminho-das-praias-da-zona-sul-do-rio-17279753.html. Acesso em: 11 nov. 2017. ${ }^{\mathrm{a}}$

HOGEMANN, Edna Raquel. Não existe justiça onde inexiste direito a memória e a verdade. In: VALLE, Vanice Lírio (Org.). Justiça e constitucionalismo em tempos de transição. Rio de Janeiro: Fórum, 2012. p. 41-55.

HOLANDA, Sérgio Buarque. Raízes do Brasil. São Paulo: Companhia das Letras, 2014. ${ }^{a}$

HORKHEIMER, M. Teoria Tradicional e Teoria Crítica. In: BENJAMIN, Walter et al. Textos Escolhidos - Teoria Crítica - Escola de Frankfurt. São Paulo: Abril Cultural, 1989. p. 125161. Coleção Os Pensadores. ${ }^{a}$

LÖWY, Michael. Ideologias e Ciência Social: elementos para uma análise marxista. São Paulo: Cortez, 2006. ${ }^{\text {a }}$

NEDER, Gizlene. Iluminismo Jurídico-Penal Luso-Brasileiro: obediência e submissão. 2. ed. Rio de Janeiro: Instituto Carioca de Criminologia/Revan, 2007. a, b, c, d, e

NEDER, Gizlene. Discurso jurídico e ordem burguesa no Brasil: criminalidade, justiça e

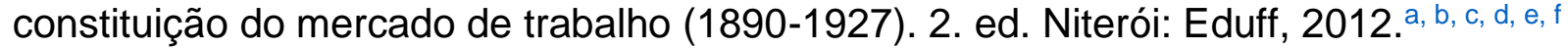

RODRIGUES, Raymundo Nina. As raças humanas e a responsabilidade penal no Brasil. Rio de Janeiro: Guanabara, 1894/1940. Acervo da Biblioteca Nacional. ${ }^{a}$ 
STRECK, Lênio Luiz; MORAIS, José Luis Bolzan. Ciência Política \& Teoria do Estado. 7. ed. Porto Alegre: Livraria do Advogado, 2010. ${ }^{\text {a }}$

TEITEL, Ruti. The Law and Politics of Contemporary Transitional Justice. Cornell International Law Journal, New York, v. 38, p. 837, 2005. Disponível em: http://ssrn.com/abstract=943069. Acesso em: 8 jan. 2017. ${ }^{\text {a }}$

ZAFFARONI, Eugenio Raul. O Inimigo no Direito Penal. 2. ed. Rio de Janeiro: Revan, 2007. ${ }^{a, b}$

ZAFFARONI, Eugenio Raul et al. Direito penal brasileiro. 4. ed. Rio de Janeiro: Revan, 2011. v. 1. ${ }^{a, b}$ 